\title{
Costs of social mobility in the context of intimate partner relationships. "It is really easy to be angry at someone who is in front of me and not at the system, which produces the inequalities between us"
}

\author{
Fanni Dés ${ }^{1}$ \\ https://doi.org/10.51624/SzocSzemle.2021.3.3 \\ Manuscript received: 3 September 2020. \\ Revised manuscript received: 29 November 2020. \\ Acceptance of manuscript for publication: 22 December 2020.
}

\begin{abstract}
Power inequalities originating from capitalist patriarchy are having an impact on and even determining our personal relationships: gender, class and ethnic inequality are consistently present in our intimate ties as well (Ridgeway 2009). For socially mobile individuals from lower classes, one of the main costs of moving between social classes is to exist in the complex conflict that arises from distancing from the social class of origin in order to integrate into new social spaces (Bourdieu 2005, Friedman 2016). These internal conflicts that are caused by broadened social structures are also present not just in the difficulty of finding a desired romantic partner (Durst at al. 2014) but in the process of sustaining an intimate relationship with someone from a particular social background as well. Structural inequalities are also determinative factors in partner selection, education homogamy and ethnic homogamy are highly present in society (Kamijn 1993, 1998, 2010, Kang Fu 2001). In this paper, through analysing narratives of educationally upwardly mobile women in Hungary, regarding intimate partner selection and looking at intimate relationships themselves, I aim to discover how their narratives reflect upon the hidden costs of mobility. I show how gender, education and ethnic inequalities emerge through the personal accounts of their mobility experiences and to what extent these inequalities determine the process of finding a desired partner or sustaining an existing intimate relationship.
\end{abstract}

Keywords: social mobility, mobility trajectory, costs of mobility, intimate relationships, gender relations, class relations, ethnic inequalities, homogamy

\section{Introduction}

During the process of conducting interviews for our research project, Social Mobility and Ethnicity: Trajectories, outcomes and hidden costs of high educational

1 Corvinus University, Budapest, Doctoral School of Communication and Sociology 
achievement, it was already clear to us from previous research results that socially upwardly mobile women frequently frame the difficulties of partner selection and further, of maintaining an intimate relationship with someone, given the social distances that become problematic and feel insurmountable through educational mobility as well as that ethnicity exacerbates these difficulties (Durst et al. 2014). In the interviews they related that they feel pressure from society to be in an intimate relationship, and they long for those relationships, but to find someone who they are able to get along with, with whom they feel to be understood, represents a major challenge for them.

When I met with Hanna a 29 year old socially upwardly mobile woman to conduct an interview for our research project, we set up our meeting in a community place in Budapest where both of us felt at home. In addition to her master studies, Hanna also works with youths from disadvantaged backgrounds. She comes from a family where both of her parents worked really hard to give Hanna the potential to gain a university degree. We more or less move in the same community, therefore the situations and feelings that she articulated during our interview about and towards her social milieu, were more or less familiar to me. However, when she was speaking to me about these situations in the context of her mobility trajectory, it was nevertheless clear to me that I never had to go through them. I never felt that I should overcome my primary socialisation to meet with the expectations of my environment, in order to feel accepted in it, which would cause constant internal conflict within me (Ingram-Abrahams 2016). The situation was the same when we got to the topic of intimate relationships. She was very thankful that we were also discussing this topic in the context of social mobility, as she felt that her mobility trajectory was, to a large extent, impacting her relationships, and that there is no place to speak about these problems. Inter alia she articulated the following:

"When I meet someone, my first two questions are what do your parents do and where did you go to school. I don't do a checklist, but I do it in some way. I know it's not the best practice but I do this because then those big surprises can't happen, like I would be surprised about what's happening. Anyway, sometimes it just comes into my mind how nice it would be if I could find for example, a carpenter, who really suits me, with whom I can really get along." (Hanna, 29, non-Roma)

Even though she had not had a partner in the last decade who came from the same background as hers, she highlighted that she feels a person from the same background of origin would be one who would suit her best. She articulated that she still feels identified with her community of origin even though in practice she has partners who come from a middle-class background that is her attained class through her mobility trajectory. She narrated the costs for socially mobile individuals of moving between 
social classes in the context of intimate partner relationships: a difficulty that exists in the complex conflict of distancing from the social class of origin, and to integrate into new social spaces as a middle-class environment (Bourdieu 2005, Friedman 2016). She explicated that she would feel more comfortable with someone who came from the same background as hers even though with her mobility trajectory; she chooses partners form her new social environment.

In my paper I aim to analyse the narratives of socially mobile Hungarian Roma and non-Roma women on finding a desired partner and in intimate relationships in the context of emotional costs (Reay 2005) or price of social mobility (Friedman 2016). I am interested in whether partner selection and maintaining an intimate relationship can be analysed in the context of the costs of upward mobility, and in examining the main articulated difficulties for women in partner selection and in intimate relationships through their mobility trajectory, taking into account the pressure from capitalist patriarchal societies to find a desired partner and to maintain an intimate relationship. My paper also covers the differences in the narratives of socially mobile women with a Roma and non-Roma background, as I take into consideration how ethnicity can affect these processes.

\section{Marriage and intimate relationships in capitalist patriarchy}

Patriarchy names the social structures that maintain the oppression of women in society through its unequal structures and social institutions (Walby 1990). The social feminist literature defines capitalism as the modern fulfillment of patriarchy, which operates through capital accumulation (Dalla Costa-Selma 1972, Seccombe [1972] 2018, Eisenstein 1977). Unequal power relations in capitalist patriarchies are also present in our intimate partner relationships (Haller 1981). Class, ethnic and gender inequalities are determining them (Ridgeway 2009). Unequal societal structures are determining our everyday life. The phenomenon that the experiences of dominant groups are accepted by society as a universal experience is present in our everyday interactions as well (Ridgeway 2009). In everyday interactions individuals can become the ones who suffer from these forms of oppression and sometimes privileged individuals are the ones who use their socially endowed power over them. Nevertheless, the causes cannot be traced only on an individual level, but can better be explained by structural inequalities of society and the unequal power relations created and maintained by social institutions of capitalist patriarchy (Marion Young 1990).

Within the institution of marriage, power inequalities are constantly present as well and this has its own societal function: capitalism exploits the institution of marriage through the logic of capitalist accumulation. The function of the institution of marriage and family in capitalism is the reproduction of life through biological reproduction and reproductive work that covers inter alia, childcare and housework. 
Reproductive work mostly carried out by women on a gender basis, which highly influences the power relations between males and females in households (Csányi et al. 2018). In capitalist patriarchal societies, reproductive work is generally assigned to women and society frames women's wage work as of secondary importance. Through this process household work becomes invisible to society; it stays in the private sphere and it remains unrespected (Fraser 2016). Therefore, the inequalities between males and females in the institution of marriage are not just simply present because of the different social positions of genders in society but also because marriage is one of the most basic institutions of the exploitation of women (Seccombe 1974). Nevertheless, the pressures on women from society and their environment to get married and raise children are determinative (Marion Young 1990). Additionally, frequently lowerclass women do not have the chance to sustain themselves economically in a oneperson household; consequently marriage is a better alternative for them (Walby 1990). A research conducted in Hungary that examined the situation of women in the country came to the conclusion, that frequently women are not able to quit their relationships, or marriages, because they would not be able to sustain themselves and their children in a one-parent household (Gregor-Kováts 2018).

In Hungary reproductive work is still highly associated with women. During state socialism the state started to involve women in the labour market to a higher extent, though lower-class women were much less affected by the idea of full employment than their middle-class counterparts (Zimmerman 2010). After the economic unsustainability of full employment became clear, state measures started to motivate women to remain out of the labour market in order to stay and work in the reproductive sphere. From the 1970s the state continuously reduced the childcare the childcare benefits (Glass-Fodor 2007) and started to reduce childcare institutions (Einhorn 1993). From the shift to capitalism from state socialism, care work was increasingly pushed to the private sphere and it became the informal work of women in households (Einhorn 1993, Gregor - Kováts 2019). Feminisation of poverty, low employment rates of women, the strengthening of the institution of family, the increased care work falling on women's shoulders became much more determinative in the country than before (Watson 1993).

On the one hand, governmental family policies clearly support upper-class families and are for the most part are gender blind as well (Szikra 2018), on the other hand because of the neoliberal provisions in the country, nowadays the emancipation policies that aim to affect women, do not reach lower-class women. It results in the status quo that lower-class women remain out of the labour market or have to work more shifts to sustain themselves and their families in addition to the care work that they have to carry out in their households for their families. A national representative research showed that for women in the country the most common problem is reconciling wage work and reproductive work (Gregor-Kováts 2019). Consequently, inequalities between males and females are present in the 
country to a high extent; additionally, governmental policies in the, last decade are more likely to deepen these inequalities rather than compensate them as well as women became more and more dependent on their breadwinner partners in the households (Szikra 2018).

Even though the proportion of first generation graduated women (58\%) in Hungary in 2016 were higher compared to the social mobility of their male counterparts (Nyírö-Durst 2021) there can be barriers that make social mobility more difficult for women based on unequal structures of society and socially constructed gender roles. For example, the different expectations towards them from their family of origin, or the expectations towards them in intimate relationships and marriages to carry out the care and housework work, besides their studies or wage work (Naudet 2018, Durst et al. 2014). For this phenomenon I will bring examples in the empirical part of my paper. In my analyses I will examine the costs of mobility in the context of intimate relationships through the narratives of our women interviewees, given they are much more pressured from the side of society to find an intimate partner, and to raise children, in addition to the expected care and household work they are required to do, based on socially constructed gender roles that can highly influence their mobility trajectory.

\section{The hidden costs of mobility in the context of intimate partner relationships}

I understand social class as a group of people who occupy the same position in production, and who have the same position in the social division of labor (Éber 2019). Wright (2003) defines five approaches through which we are able to define class positions: class as a subjective location, class as objective within distributions, class as the relational explanation of economic life chance, class as a dimension of historical variation in systems of inequality, and class as a foundation of economic oppression and exploitation. In Hungary based on its semi-peripheral ${ }^{2}$ regional position in the global economy there is a comparable middle class as in centrum countries where there is an economic basis for a wide middle social stratum. In the semi-periphery the economic circumstances of the middle social stratum are much more vulnerable compared to centrum countries (Éber 2020, Huszár-Berger 2020), even though there is a social stratum that cannot be labeled as lower or upper class. Éber (2020) calls this social stratum as "mediator" class. I will interpret the social mobility of our interviewees as a position change in class structures as they cannot be defined as labourers with their movement compared to most of their parents -

2 According to Wallerstein's world system theory (1972) one is able to examine the structures of capital accumulation on a world system scale, as due to unequal geographical development there are unequal exchange relations between the different regions of the world, which are deeply affects the different nation states internal class structures. Centrum countries are exploiting the countries which are located in peripheral regions, and the semi-peripheral countries are in a dual role in the exchange relations: they are exploited by centrum countries but exploiting the peripheral countries. 
and they had and have to prevail in a really different social medium as their parents had to. This paper concentrates on the subjective price (Naudet 2018) of changing position in social class structure in the context of intimate relationships.

The academic literature that concentrates on the costs of social mobility explores how social inequalities determine the everyday experiences of socially mobile individuals (Reay 2015), and how these experiences differentiate from the experiences that society treats as universal, as well as from the common experiences of different social classes (Bourdieu 1984: 97-256). The most highlighted cost of social mobility for individuals is to experience the internal conflict of not feeling that they belong anymore to the background of origin (family, friends) nor to be an integral part of middle or upper-class community that should be the new medium of the individual based on its mobility trajectory. That is, the individual is not able to identify with the common experiences of lower-class people anymore nor with the common experiences of upper-class groups (Bourdieu 2005, Friedman 2016).

Bourdieu (1984: 97-256) uses the term class 'habitus' for universally accepted behaviours within social classes. "Habitus results from early socialization experiences in which external structures are internalized" (Swartz 1997: 103). Class habitus is determined by unequal social structures and offers guidelines for individuals on how to act properly in a given social environment. Within different social classes, different habitus is accepted and appreciated (Friedman 2016). Individuals who have the same life chances in society share a common habitus, that is determined materially, socially and culturally (Swartz 1997: 95-116). Mobility is an ideal phenomenon for the examination of social class habitus as well as for the examination of how individuals deal with the phenomenon that it is expected from them to adapt to a new habitus of a new environment and to become accepted in it. These processes often appear in the internal conflict within the individual between feeling loyalty towards the environment of origin and family, and between the possibilities of mobility (Friedman 2016). Therefore, the process often involves that socially mobile individuals abandon some of their motivations regarding their mobility in order to remain accepted by their community of origin. These are barriers that their upper-class counterparts do not have to deal with. This phenomenon can be understood as a cost of mobility, as it results in a constant internal conflict within the individual (Mallman 2015). Bourdieu $(1999,2000)$ refers to the phenomenon 'divided habitus' when socially mobile individuals experience an internal conflict between the habitus of their class of origin - which they learned through socialisation - and between a middle, upper-class habitus, which is expected from them during social mobility. This internal conflict can also appear during the process of partner selection as well as in the process of maintaining a relationship with a partner from a given social background (Durst et al. 2014). A lot of our interviewees did not achieve much better economic circumstances for themselves compared to their parents. Nevertheless, with their educational mobility and the distinction of their 
primary socialisation in their community of origin, the compliance difficulties in their new, more educated attained group is clearly present in their narratives and results in constant internal conflict within themselves.

Based on the data of the census in 2011, the comparison between Roma college educated individuals (most of them generally first generation graduates according to previous research results) and Hungarian first generation degree holders, shows that the proportion of unmarried individuals is much higher among Roma graduates than among their non-Roma counterparts. 39\% of Roma male and $44 \%$ of Roma female graduates were unmarried in Hungary in 2011, meanwhile the correspondent data is $27 \%$ of male and $29 \%$ of female for the total population (Nyírö-Durst 2021). Durst et al. (2014) examined the hidden costs of mobility amongst Roma women, and one of their main conclusions was that one of the most frequently mentioned costs of upward mobility among first generation graduate Roma women was the difficulties of finding a desired partner. Women were aiming to find a partner and to maintain a relationship but they shared that they constantly faced difficulties in the area of intimate relationships. Many of these difficulties can be explained by their mobility trajectory. Furthermore, another frequently mentioned problem was 'socially downward marriage'. Women had partners who were not socially mobile, therefore after a while they felt that their relationships became empty, their partner experienced a feeling of inferiority towards them because of their socially lower status, and consequently the marriage was not sustainable in the long term. Naudet (2018) in his book examines the costs of mobility through the narratives of socially mobile individuals in three countries ${ }^{3}$, who managed to step into elite circles. He also provides examples from his sample for whom the difficulties of maintaining a relationship or ending a relationship were explained by the different class socialisation of partners. It will be seen in the empirical part of my study that the intimate relationships of our women interviewees were highly determined by the conflicts which originated from the different backgrounds and different education levels of the partners. They felt on the one hand that if they choose a partner with the same background as theirs, then their partner would not be able to understand their motivations, but on the other hand, if they chose someone from their new status without a mobility trajectory then their partner would not be able to understand their background. As such, they also felt themselves to be in no man's land (Durst et al. 2014: 175) in the context of their intimate relationships: their relationship preferences and their conflicts within their relationships were highly influenced by structural inequalities.

The intersectionality of ethnicity and gender will be present as a concept in my analysis (Crenshaw 1989, 1991) since we also conducted interviews with Roma and non-Roma women. The concept of intersectionality was coined by Kimberly Crenshaw

3 The research was conducted in India, in the USA and in France. 
$(1989,1991)$ to highlight the differences between the everyday experiences of black women compared to white middle-class women that were engaged in the 60-70s women's movement in American society. Intersectionality posits that everyday experiences of women from different social classes and ethnic backgrounds are not the same, based on their different economic and social position (Yuval-Davis 2006). Therefore, women with different class and ethnic backgrounds can have distinct experiences on the relationship and marriage market as well. Lower class and minority ethnic positions can both be present in the unequal power positions in a relationship, through maintaining a relationship with a partner from a given social background in Hungarian society where the discrimination of Roma people by social institutions is highly present (Ladányi 1996, Ladányi-Szelényi 2002, Szalai 2002, Bernát 2014). Despite this, Roma people constitute a heterogeneous group given that people generally, in social reality, are lumped together and are often judged by the majority as a homogenous group in Eastern Europe involving Hungary as well (Kligman 2001). For the Roma women in our sample, an important aspect in partner selection was whether someone had a Roma or non-Roma background. These expectations mostly originated from their bad experiences in Hungarian society from majority groups and from their non-Roma partners. During our research, it frequently came up that the partners had prejudices towards our interviewees. Roma women also felt that their non-Roma partner was not able to understand their everyday realities shaped by discriminatory experiences.

\section{The function of marriage and intimate relationship in sustaining inequalities}

It is not just the unequal social structures that determine our relationships but the institutions of marriage and family are one of the most determinative factors in sustaining class inequalities through marriage and relationship homogamy. Additionally, class socialisation happens through these institutions as well and this deepens the boundaries between classes (Haller 1981) and extract class habitus as a phenomenon (Bourdieu 1984: 169-208).

In our everyday life we contextualise love as being unpredictable, emotions would be the only factor that would determine the process of choosing an intimate partner. Society frames finding the right partner as one of the most important indicators of finding happiness in life (Illouiz 1997: 25-48). This framing of partner selection is part of the process of how society frames phenomena and institutions in a liberal individualistic context: this framing suggests these societal phenomena would exist in a vacuum and not in a society that is shaped by unequal social structures (Marion Young 1990). Throughout history, partner selection and marriage always had its societal function. Within as well as without the institution of marriage (Illouiz 2012: 18-59). Even if it is not openly regulated nowadays, partner selection 
and marriage still has its function to maintain the status quo and to sustain the inequalities between social classes (Haller 1981, Lőrincz 2006). Despite the fact that from the eighteenth, and nineteenth centuries partner selection is framed in western countries with love being the most significant factor in finding the 'right' partner (Illouiz 2012: 18-58, Fáber 2019). The consequences of the process that society frames love as the foundation of marriage, is that the function of marriage in maintaining unequal structures became much more invisible for society (Illouiz 2012: 18-58, Fáber 2019) but did not disappear in social practice. Additionally there are still several regions in diverse countries around the world where marriage is not framed as a free choice, for example there are numerous countries where forced marriage is a general phenomenon (K.Gill-Anitha 2012: 10). For our interviewees, in the context of partner selection, the dilemma of choosing a partner with the same background that they originate from, or from their new, more educated environment, constantly appeared.

Educational and ethnic homogamy are one of the most determinative factors in partner selection (Kamijn 1993, 1998, 2001, Kang Fu 2001). It is dictated by the circumstance that the myth of free choice in partner selection is limited to choosing a partner within our social class and ethnic group (Haller 1981, Blau et al. 1994). These mechanisms can originate from pressure arising from society, family, community, class socialisation and social segregation, that is from the social process that through segregated social institutions only people from the same class and ethnic groups are able to make contact with each other. Consequently, individual choice and social determination are present in parallel in the process of partner selection (Haller 1981). This determination on an individual level can be attached to class habitus (Bourdieu 1984: 97-256) as it is easier to base intimacy and an understanding relationship with someone who has the same primary socialisation as you and has similar everyday experiences. In addition to this a person's environment needs to be acceptable to her/his chosen partner.

In Hungary homogamy between classes reveals different patterns based on education attainment. The greater the distance between an individual's educational level, the less likely it will be that they will marry. Upward marriage is most likely among females and males who have attained eight grades of primary schooling. Educational homogamy has the highest rates between people who have a university degree or the ones whose level of education is at most elementary school (Bukodi 2002). Family also has a crucial role in homogamy. In Hungary those who have the same level of education as their father are most likely living in homogamy relationships. For females, in contrast to their male partners, if they are socially upwardly mobile, then downward marriage in terms of educational level is more prevalent than homogamy (Bukodi 2002). Literature highlights education as the most prevalent factor in marriage homogamy (Kalmijn 1998, 2010, Kang Fu 2001). 
Theories concentrating on ethnic homogamy explore to what extent marriages are homogeneous or heterogeneous in a given society (Kang Fu 2001). There are many social factors that influence how frequent it is that individuals choose partners outside from their social groups. For example, one of the factor is the way a given minority group's social position is defined by the majority society, another one is economic and social position of the group, the third one is the social distance between different social groups. Regional segregation can also be a determining factor, as research has proved that in more heterogeneous cities the rates of mixed marriage are much higher (Tóth-Vékás 2008, Blau et al.1984). In Hungarian society marriage homogamy rates are very high between different Roma groups, which can be explained by the significant social segregation in the country. Based on the census of 2001, 83,1 percent of Roma males and 84,9 percent of Roma females in the country lived in a homogenous marriage (Tóth-Vékás 2008). Other research showed in 2013 that among Roma youth homogamy is a strong preference factor in partner selection (Lőrincz 2013).

\section{Methodology}

This paper is an outcome of the research project 'Social Mobility and Ethnicity: Trajectories, outcomes and hidden costs of high educational achievement. ${ }^{4}$ Our research group systematically analyses the costs of upward mobility in Hungary from different perspectives through the self-narratives of educationally mobile individuals. The research is mainly conducted with qualitative methods; our methodology is based on semi-structured, in-depth, narrative interviews. Furthermore, we intend to combine in-depth, life course interviews and case studies of mobility aiding support programmes or initiatives, with quantitative data regarding the social group of first generation graduates (Ferenczi 2013). We define first generation graduates during our research as individuals whose parents do not have any higher education degrees and who have graduated from college or university.

Altogether we made 140 interviews with Roma and non-Roma first generation graduates, which gives us the possibility of examining the role of ethnicity in social mobility and also the subjective way in which individuals experience it. Research participants were recruited through snowball sampling. We used different channels to find our participants, we also interviewed first generation graduates who had participated in our former research (Durst et al. 2014), we were looking for participants through making contact with generic Roma and pro-Roma institutions. We used our own personal networks in the research team, and we also gathered participants through online media and Facebook advertisements.

4 K-125 497 OTKA project entitled 'Social Mobility and Ethnicity: Trajectories, Outcomes and Hidden Costs of Mobility', supported by a Hungarian Academy of Science (NKFHI) research grant. 
For the purpose of this paper I analysed twenty-three interviewees from our sample with Atlas.ti software, from which all the interviewees were female. From the twentythree participants, fourteen females identified as Roma, the other nine women come from a non-Roma background. Three of our interviewees were less than thirty years old, eight were in the age group ranging from thirty-one to thirty-nine, another eight were between forty and forty-nine and two of our interviewees were more than fifty years old. We conducted interviews in different regions of Hungary and our sample includes interviews with people from different settlement types. I changed the real names of our respondents so that our interviewees are not recognisable.

During our interviews and our analyses we put an emphasis on partner selection and on maintaining romantic relationships with a partner, given it became clear from the academic literature and from former research (Durst et al. 2014, Naudet 2018) that hidden costs of mobility can also present in the context of intimate partner relationships based on the narratives of socially mobile individuals. It should be taken into consideration that finding a suitable partner and maintaining a relationship even if it is a desire for someone, can have many barriers that are not attached to social mobility, but to other societal or psychological reasons. In my paper I aim to highlight the pressures and barriers attached to intimate relationships linked to the costs of social mobility, but in most of the cases I draw attention to the complex internal processes framed by the pressures of the society one belongs to.

\section{Hidden costs of social mobility in the context of intimate partner relationships through the narratives of socially mobile women}

In the following, I analyse the narratives of socially mobile Roma and non-Roma women through different aspects of their difficulties caused by their upward mobility trajectory in finding a desired partner and in maintaining a relationship. I identify these difficulties as a cost of social ascension originating from the unequal structures of society.

\section{Conflicts arising from expectations regarding gender roles}

Due to socially determined gender roles in intimate partner relationships, there were several problems which were mentioned during the interviews. The most significant conflict that was present in the narratives was that the partners had different ideas on gender roles, which mostly originated from their learned family patterns. As with all societies, and to some extent in Hungary, socially constructed gender roles in the institution of family are common, for example, the care work mostly falls on the shoulders of women. In his research Naudet (2018) conducted among first 
generation graduate in three countries ${ }^{5}$ he interprets several narratives where first generation graduate women narrate that their parents were not as supportive of them during their mobility trajectory as they were with their brothers, citing gender as the reason. The women with whom we conducted interviews said that even though they were full time students or active on the labour market, socially determined gender roles frequently caused conflict in their intimate relationships. In several relationships it was expected that they carry out the care work at home in addition to their studies or their paid work.

One of Kata's relationships ended because of unequal gender role expectations from her partner. She highlights that in her family, gender-based roles did not exist, contrary to her boyfriend's family where these roles were framed. Lilla also recounts that one of her partners could not understand her ambitions instead of choosing to serve him.

"In his family gender roles were totally different than they were in my family. The expectations of the roles of woman and man. For example, when I was preparing for my final exam at the uni, I still had to make dinner for him. I only asked him to clean the table after the dinner. And he answered that he will not, how can I even imagine that a man with a precious hand [he was a musician] would do that? That was when I started to shout..." (Kata, 37, Roma)

"The biggest conflict in our relationship was, that he did not understand why I still wanted to work and study when he earns that much. He would expect me that when he arrives home the meal should be ready and everything should be done." (Lilla, 41, Roma)

Judit said that she could not manage to fit in to the socially determined gender roles in her relationship and she saw this as a failure. Even though she highlights that she thinks it is unfair that even though they finished work at the same time, her partner still expected her to cook dinner. Enikő highlighted that she was not able to identify with socially determined gender roles, and this had caused a lot of conflicts at the beginning of her marriage.

"I couldn't always succeed to be in the typical female role a hundred percent. I can tell you an example. We went home from work around seven o'clock. We finished at the same time. And it was expected that I start to cook." (Judit, 41, Roma)

"I grew up in a family where traditional gender roles were evident. And at the beginning of our relationship there were a lot of conflicts based on that. By the way I am not able to really identify that a woman has to do things because she is

5 The research was conducted in India, in the USA and in France. 
a woman and the man has to do the other stuff. I think a man can cook and wash dishes as well. He can also take care of the children." (Enikő, 43, Roma)

In the narratives of our respondents, it appears that even though women had jobs and/or were studying, their partners expected them to serve them and to do the housework based on socially constructed gender roles in the institution of family that frames house and care work as 'female jobs'. All the interviewees tried to some extent fulfill their 'womanly' role in their relationships, even Kata, who before she started to shout at her partner, still made him dinner, despite the fact that she had to study. The pressure from society to fulfill socially constructed gender roles is significant and widespread (Marion-Young 1990, Walby 1990, Ridgeway 2009). The gender role expectations from women in relationships and households can be examples of how structural inequalities appear and how power imbalance is materialised between two individuals who have different social positions in society. Women with middle or higher-class backgrounds are more likely to work on the labour market than their lower-class counterparts in Hungary, whose work is more frequently performed stays in the domestic sphere. If they are able to be present on the labour market, they are frequently working more shifts besides their care and house work (GregorKováts 2019). It aggravates the situation that governmental public policies also motivate to keep socially constructed gender roles in the household and women to stay in the reproductive sphere instead of counterbalancing these inequalities in the institution of family (Szikra 2018). Expected gender roles in intimate relationships can push women to abandon their motivations of social mobility to be able to fulfill the expectations of their male partner in the household.

\section{The role of mobility in finding a desired partner}

In the second part of my analyses I concentrate on how education and ethnic inequalities can determine the process of finding a desired partner on the relationship market for upwardly mobile women. The search for a desired partner caused difficulties for the majority of our female interviewees. In her narrative, Kata related that partner selection is difficult between any two people who have high achieving goals. She points out that the twin goals of building a high achieving career and being conscious about finding a desired partner and planning a family, is not an easy challenge for women in Hungary. Even though she already has a family, she articulated that it was hard to find a proper partner for herself and she really empathised with her friends who had not managed to find a partner yet.

"It's the easiest thing to maintain a relationship. But you are concentrating so much on going forward with your life and with your career, you have to make an existence, you have to learn, achieve things. The competition is awful. And for 
planning an enduring relationship, with a family besides, you have to be very conscious." (Kata, 37, Roma)

It was frequently articulated when discussing partner selection that the ideal partner has the same ethnic background and mobility trajectory as the interviewee. Consequently, the ideal partner is one who has the same social mobility experiences so that during the course of the relationship, there are no conflicts based on education differences and ethnic inequalities, or different social experiences in society. Laura, a sixty-year old divorced Roma woman with two children, narrated that her marriage fell apart because she already had two children when she was studying at university and her husband had to take care of the children, while she was studying. He could not understand why studying was so important for her. Afterwards she could not conceive of starting a relationship with a non-Roma partner as ethnicity was an important factor for her in partner selection, her former husband came from a Roma background as well. Nevertheless it was difficult to find someone among the Roma community who had the same education level as hers and she did not want to repeat the failures of her first marriage. She formulated that for someone to choose a Roma partner it is not just an individual choice or preference, it is already a statement towards society as well.

"A non-Roma graduate male probably will not choose you as a partner as it is already a statement, a societal commitment. It's not just an emotional commitment to marry a Roma woman. And when I was at the Romaversitas there were a lot of graduate Roma men and women therefore it was much easier, a lot of Roma youngsters entered in marriage there." (Laura, 60, Roma)

During the interviews, it was frequently mentioned that being part of a minority ethnic group makes the process of partner selection much harder. Kata stated that being Roma and choosing a Roma partner could cause a lot of difficulties as well, as your family could be more judgmental with your partner. Her parents once banned her from being friends with one of her schoolmates as she had a Roma background and they were worried that she would have a bad influence on her given Kata's family were more assimilated in the majority society. Therefore, she had former negative experiences of her family being judgmental when she engaged with people from a Roma background. As previous research (Kligman 2001) has also reported, this is a frequent answer on the side of Roma people to the prejudices constructed by majority groups to distance themselves from other Roma people or other Roma sub groups under the label that they are "not like them". Even though she states that if you choose a non-Roma partner it is hard to find someone who really understands your everyday reality, who really accepts your background, therefore it was her conclusion that to find a proper partner who you are able to get along with, is difficult anyway. 
"There is that thing, if you are a Roma graduate woman and you are with a Roma man there is a family pressure that you can deal with or not. And then you will choose a non-Roma partner. But the consequences of choosing a non-Roma partner are difficult as well, to find someone who is totally acceptable with your background and who is able to integrate to your family. I think it is hard." (Kata, 37, Roma)

Enikő stated that she was not able to explain why it had been important for her to find a partner with the same ethnic background as her own, even though she pointed out that it was very difficult. She got married in her late twenties after a long-standing desire to find a partner.

"I know it is not a good thing but I also chose my partner on an ethnic basis. I know it sounds weird but at that time I felt like I had to choose a Roma man. I don't know why I felt that. And it was really hard to find someone with whom I am able to discuss things, who has the same interests as me." (Enikő, 43, Roma)

The narratives on partner selection clearly show that to find a proper partner on the relationship market is not just framed by individual preferences and goals, but is also framed by the expectations of family. In addition by the need to find a partner who could understand and be supportive about the individual's social position, and who also accepts and is accepted by the individual's ethnic background and her family. The narratives clearly highlight that apart from the interviewee's mobility trajectory, a Roma ethnic background makes it even harder to find a suitable partner. Regarding the last census in Hungary in 2011, only 1,7 percent of the Roma population has a higher education degree (KSH 2011) which can be explained by the high level of social and educational segregation of Roma people in Hungary (Ladányi 1996, LadányiSzelényi 2002, Szalai 2002, Bernát 2014). Therefore, to fulfill the need to find a partner from the same, Roma ethnic background as well as with the same education level can be a challenge in Hungarian society. However, as our research sample shows, some academically high achieving Roma managed to overcome this challenge and have gone on to form stable, long lasting marriages from this circle.

Our research participants also highlighted the fact that their social mobility trajectory had caused difficulty in finding a desired partner. The fact that they are not able to serve the social function of partner selection to sustain class inequalities, makes it harder for them to find a desired partner (Haller 1981): on the one hand, if they choose a partner who comes from the same background of origin as themselves but did not also have a social mobility trajectory, then, intellectually they are not compatible. On the other hand, if they choose a partner who does not have the same social position as them and their family of origin, it is equally hard to find someone who will understand their social reality, and who will accept them as well as their community of background. 


\section{Education inequalities within intimate relationships}

The women in our research sample also narrated the difficulty of sustaining an intimate relationship with a partner who does not have the same mobility trajectory as them. I bring two examples from our interviews. The first example shows the difficulties of a relationship when the partner has an upper-class background. The second example highlights the conflict originating from the situation when a partner comes from the same background as our interviewee but he has no mobility trajectory. Hanna, who only ever had partners who came from a middle-class background narrates that there were several conflicts in her relationships that originated from class differences. Rita explained that her first relationship did not work out because her partner had a lower education level than hers and he could not deal with his "inferiority complex".

"I had a one and half year, a four year, and another one and a half year relationship which were long-term intimate relationships. The conflicts which were coming from class differences were really determinative in all of them. The fact that you came from somewhere else, that you can't speak the language, you are not able to recognise the reference points, you are not laughing at jokes that others do, it is really determining your everyday reality. And a lot of times I became upset and started to blame my partners. It is really easy to get angry at someone who is in front of me and not at the system, which produces the inequalities between us. It frequently happened, it was really typical, that I told them why didn't you choose a woman who is coming from the same background as you? When something painful happens to me it is frequent that I start to blame them, but this is really not conscious. And of course these statements are really painful for them and it is always happening." (Hanna, 29, non-Roma)

"He didn't have a university degree, He had eight grades, elementary school. And it wasn't important for me at the time, I was twenty-one years old. He was my classmate in elementary school. We never had any contact but once we were running into each other in a party and I realised that he is not that bad at all. And something is started between us. And I told him that it doesn't bother me but he was really annoyed by this. Obviously, he had an inferiority complex that maybe was there already, without me. And he was really annoyed by this, that I only had friends who had degrees. But obviously I had friends from my high school; I didn't really have contacts with my classmates from elementary school. And I didn't directly choose friends from high school but it came with my life situation. He wasn't able to understand this. I tried to be more understanding and supportive; I was helping him study to get a high school degree. His parents would be so happy about it as well. Once we decided he will do it but after he gave it up. And I still think that it is not important. But if it is causing that much conflict it is not worth it." (Rita, 42, non-Roma) 
Success due to being in a relationship with a partner who has not previously experienced a mobility trajectory earlier, also appeared in some of the narratives. Laura stated that it is highly important for her to have partners who have a higher education degree and she related a story about how one of her partners finally went to university because she motivated him and she framed it as a success in the relationship.

\footnotetext{
"It was always important for me. My former partner went to university because of me and he did it...He had only a high school degree and he got the degree for me. Or not for me, just that it motivated him that he was with me. It's important for me to have someone with whom I am able to talk, who is interested in things, who has an opinion and has questions about the world as well." (Laura, 46, Roma)
}

Rita highlights that she feels guilt regarding the fact that she was upwardly mobile unlike her partner. She feels that she should explain why she has not had lower class friends and she tries to help her partner in his studies. Hanna is angry as she did not have the middle class socialisation that her partners did, and therefore she needs to study what is natural knowledge for them. Bourdieu $(1999,2000)$ and Friedman (2016), among others, conclude that the same attitudes - anger and guilt - are attached to the divided habitus that many upwardly mobile people experience, and these feelings are also attached to the costs of mobility. Laura also motivated her partner to achieve the same education level as hers, in order to have a partner with a similar mobility trajectory as hers. The narratives clearly show the structural inequalities between social classes and also, that class struggle can appear and cause ongoing conflicts in interpersonal and intimate relationships.

\section{Ethnic inequalities within intimate relationships}

Ethnic inequalities also frequently came up in the narratives as difficulties in intimate relationships. Durst et al. (2014) also mention in their paper that a common narrative among their Roma women interviewees is that, after experiencing conflict caused by coming from different social positions and originating from distinct ethnic backgrounds in their previous relationships, women decided afterwards not to start a relationship with partners, who did not have experience of the oppression of minority groups in society as it caused a lot of difficulties in maintaining the relationship. In our sample one of the most frequent distresses that was highlighted by our Roma women respondents was the moment when they had to reveal their ethnic background of origin at the beginning of their relationships. Lilla recalled a conversation that happened in one of her relationships when she told her partner after a few dates that she was Roma and her partner reacted with surprise and with negativity, even refusing to acknowledge the information. Zsuzsa was forced by her 
parents to tell her partner that she is Roma as they were worried that her partner would not be willing to go out with her anymore if he found this out.

- "You what? You are not (Roma).

- Yes, I am. If you take me to Szigetvár you will see that my mother is that (Roma) as well.

- Really?

- Yes. What's up? Should I leave? - But this conversation was at Terecsényi tető. - I should get out?

- No. You are not that (Roma). - And he didn't speak with me till Szigetvár." (Lilla, 41, Roma)

"And my parents told me: you should tell him immediately that you are a Roma woman, don't fool him, anyway his parents will not let him go out with you. And I told them okay, and went to him and I told him that I would like to tell him an important thing. And then I told him and he hugged me, he is a very big man, he is around two meters and the way he hugged me with his huge hands and gave me a lot of kisses and he told me that he knew it, but he didn't care because he adores me." (Zsuzsa, 47, Roma)

It was also a frequently mentioned problem during our interviews that individuals originating from minority ethnic backgrounds grew wary of the fact that their partners were not able to understand the everyday harsh reality of discrimination and stigmatisation, on the basis of their ethnicity. They did not understand what they have to face in everyday life as a member of a stigmatised minority group. Juli mentions that it was very difficult when she had a non-Roma partner and she always had to explain what it means to be Roma in Hungary.

"I had one boyfriend who wasn't Gipsy and it was so hard to explain everything to him. That as a Gipsy my experiences are these and that, and this is racism, this is discrimination. You know, I had to explain everything because he wasn't Gipsy and he never met with this, he had that privilege." (Juli, 30, Roma)

The fact that the fundamental moment that Roma women tell their partners about their minority background causes immense stress for them, clearly points out the enormity of what their background means in their everyday reality. Regardless of the reactions of their partners, whether it confirms these women's fears of coming out with their ethnic origin, or not, their fear shows that it is something that can be problematic, or you can choose to overlook it. In the context of maintaining a relationship with a partner coming from a different ethnic background, a similar problem came up when the interviewees were narrating the conflicts based on class 
differences: it is hard to sustain a shared life with someone to whom you always have to explain your social reality.

\section{Conclusions}

Our women interviewees clearly pointed out that the consequences of upward social mobility via academic high achievement can appear during partner selection and during the process of maintaining a relationship as well. A Roma ethnic background can also appear as a determining factor in the context of intimate relationships and the intersection (Crenshaw 1988, 2001) of social mobility and ethnicity, or rather racialized minority origin can make it even harder to find a desired partner. The narratives clearly highlight that most of our women interviewees framed an ideal partner as someone who has the same social mobility trajectory and ethnic background as themselves, in order to feel understood. Even though theythey highlight that especially for women with Roma background of origin it is a a challenge to find a partner with these characteristics.

It was also highlighted that socially constructed gender roles often caused problems in relationships, on the one hand because they could not accommodate these roles in addition to their ambitions, but on the other hand, their partners preferred to be served and they could not understand why they chose their ambitions instead of fulfilling these expectations. Therefore, socially constructed gender roles that arise from the oppression of women in capitalist patriarchal societies are able to highly influence the extent of women's social mobility.

Even though the context of semi-peripheral class structures of Hungarian society clearly appear in the economic situation of our interviewees, and despite the fact that they were educationally mobile, plenty of them were not able to reach much better economic circumstances than their parents, other factors induced them to deal with the costs of mobility and with the differences in class habitus of their background of origin and their new, attained social group: they feel that they have to meet the expectations of a very different social milieu. The conflicts originating from a different education level and ethnic societal position emerge as the relationship with an intimate partner progresses, as well. To be with a partner who can be identified with the background of origin can be attached to a feeling of guilt. Conversely, to be with a partner who is part of the new, upper-class social milieu can be identified with feelings of frustration and anger. These feelings can be identified with the phenomenon of divided habitus (Bourdieu 1999, 2000, Friedman 2016), and can be embodied towards someone who is "produced by the system and not towards the system itself".

Our research participants narrated that the consequences arising from their upward social mobility appear as a factor in partner selection and within their intimate relationships, and that they are faced with the costs of social mobility 
(Friedman 2016) in finding a desired partner or in maintaining an intimate relationship as well. In their narratives it appears that if you are not able to find a partner who has the same experiences as you, from your social position, you will not be understood, you will have to constantly explain your social reality to your partner, and during the relationship a lot of conflict emerges from these differences. Consequently, upwardly mobile women also feel themselves to be in a "no man's land" (Friedman 2016) in the context of intimate relationships and during a relationship, if they have to maintain it with someone who did not experience social mobility, or who comes from a different ethnic background. It supports the fact that partner selection in capitalist patriarchal societies is highly determined by structural inequalities (Haller 1981, Lőrincz 2006) as if you are socially mobile you are not able to meet with the order to sustain education and ethnic inequalities, you are not able to choose a homogenous partner and it makes it harder to find a partner, to sustain a relationship. These experiences serve as a good illustration of how structural inequalities are constantly present in our interpersonal relationships and consequently how the costs of social mobility can determine an individual's most intimate spheres and relations.

\section{References}

Anitha S. K. - Gill A. (2012): Introduction: framing forced marriage as a form of violence against women. 1-24. In Anitha S. K.-Gill A. (ed.) Forced Marriage: Introducing a social justice and human rights perspective. London-New York: Zed Books Ltd, 147-159.

Blau, P. - Joseph E. J. S. (1997): Crosscutting Social Circles. Testing a Macrostructural Theory of Intergroup Relations. New York: Routlledge. https://doi.org/10.4324/9781351313049

Huszár Á. - Berger V. (2020): Az új középosztály? Politikatudományi Szemle. 29(2): 71- 99. https://doi.org/10.30718/POLTUD.HU.2020.2.71

Bernát A. (2014): Leszakadóban: a romák társadalmi helyzete a mai Magyarországon. Chapter: 11. Tamas K. - Toth I. Gy. (szerk.): Társadalmi riport. Budapest: TARKI Social Research Institute, 246-264.

Bourdieu, P. (1984): Distinction. A social critique of the judgement of taste. London: Routledge.

Bourdieu, P. (1999): The Weight of the World. London: Polity Press.

Bourdieu, P. (2000): Pascalian Mediations. Cambridge: Polity Press.

Bourdieu, P. (2005): The social structures of the economy. Cambridge: Polity Press.

Blau, P. M. - Beeker, C. - Fitzpatrick, K. M. (1984): Intersecting Social Affiliations and Intermarriage. Social Forces, 62(3), 585-606. https://doi.org/10.2307/2578701

Bukodi E. (2002): Ki kivel (nem) házasodik? A partnerszelekciós minták változása az egyéni életútban és a történeti időben. Szociológiai Szemle, 2: 28-58. 
Csányi G. - Gagyi Á. - Kerékgyártó Á. (2018): Társadalmi reprodukció. Az élet újratermelése a kapitalizmusban. Fordulat, 24:5-31.

Crenshaw, K. (1989): Demarginalizing the Intersection of Race and Sex. A Black Feminist Critique of Antidiscrimination Doctrine. Feminist Theory and Antiracist Politics. University of Chicago Legal Forum, 1(8): 139-167.

Crenshaw, K. (1991): Mapping the Margins: Intersectionality, Identity Politics and Violence against Women of Color. Stanford Law Review, 43(6): 1241-1299. https:// doi.org/DOI: 10.2307/1229039

Dalla Costa M. - Selma J. (1972): The Power of Women and Subversion of the Community. London: Falling Wall Press.

Durst, J. - Fejős, A. - Nyírő, Z. (2014): “I always felt the odd one out”: Work-life balance among graduate Romani women in Hungary. Acta Ethnographica Hungarica, 59(1): 165-190. http://dx.doi.org/10.1556/AEthn.59.2014.1.8

Éber M. Á. (2019): Osztályszerkezet Magyarországon globális perspektívából. Fordulat, 26(2): 76-114.

Éber M. Á. (2020): A csepp. A félperifériás magyar társadalom osztályszerkezete. T. E. M. társadalom elméleti múhely. Budapest: Napvilág kiadó. EIGE (2016): Poverty, Gender and Intersecting Inequalities in the EU. Review of the Implementation Area A: Women and Poverty of the Beijing Platform for Action. European Institute for Gender Equality. https://eige.europa.eu/publications/poverty-gender-and-intersectinginequalities-in-the-eu (downloaded: 2020.07.03)

Einhorn, B. (1993 [1991]): Hová lett a sok nő? A nők és a nőmozgalmak Kelet-Közép -Európában. Tér és Társadalom, 7(1-2): 51-57.

Eisenstein, Z. (1999): Constructing a Theory of Capitalist Patriarchy and Socialist Feminism. Critical Sociology, 25, 196-217.

https://doi.org/10.1177/08969205990250020901

Fáber Á. (2019): Az autotelikus párkapcsolat és a gyerekvállalás mint „metaprojekt”. Replika 110: 95-133. https://doi.org/10.32564/110.4

FRA Technical report (2014): Technical report. Violence against women: an EUwide survey. Survey methodology, sample and fieldwork. https://fra.europa. eu/en/publication/2014/violence-against-women-eu-wide-survey-surveymethodology-sample-and-fieldwork (downloaded: 2020.07.03)

Fraser, N. (2016): Contradictions of capital and care. New Left Review, 100:99-117.

Friedman, S. (2016): Habitus clivé and the emotional imprint of social mobility. The Sociological Review, 64(1):129-147. https://doi.org/10.1111/1467-954X.12280

Glass C. - Fodor (2007): From Public to Private Maternalism? Gender and Welfare in Poland and Hungary after 1989. Social Politics: International Studies in Gender, State \& Society 14(3):323-350. https://doi.org/10.1093/sp/jxm013

Gregor A. - Kováts E. (2018): Nóügyek. Társadalmi problémák és megoldási stratégiák. A kutatási eredmények összefoglalója. Budapest: Friedrich - Ebert - Stiftung Budapest. 
Gregor A. - Kováts E. (2019): Work-life: balance? Tensions between care and paid work in the lives of Hungarian women. Social Science Review, Special Issue in English (7). https://doi.org/10.18030/socio.hu.2019en.91

Haller M. (1981): Marriage, Women and Social Stratification: A Theoretical Critic. American Journal of Sociology, 86(4): 766-795.

Ingram, N. - Abrahams, J. (2016): Stepping outside of oneself. How a cleft-habitus can lead to greater reflexivity through occupying 'the third space'. In Tatcher, J. - Ingram, N. - Burke, C. -Abrahams, J. (ed.) Bourdieau: The Next Generation. The development of Bourdieau's intellectual heritage on contemporary UK sociology. New York: Routledge.

Illouz, E. (1997): Consuming the Romantic Utopia: Love and the Cultural Contradictions of Capitalism. London: University of California Press.

Illouz, E. (2012): Why Love Hurts. A Sociological Explanation. Cambridge: Polity press.

Kamijn M. (1993): Trends in Black/White Intermarriage. Social Forces, 72(1): 119146. https://doi.org/10.1093/sf/72.1.119

Kamijn M. (1998): Intermarriage and Homogamy: Causes, Patterns, Trends. Annual Review of Sociology, 24: 395-421. https://doi.org/10.1146/annurev.soc.24.1.395

Kamijn M. (2010): Educational Inequality, Homogamy and Status Exchange in Black - White Intermarriage: A Comment on Rosenfeld. American Journal of Sociology, 115(4): 1252-1263. https://doi.org/10.1086/649050

Kang Fu V. (2001): Racial Intermarriage Pairings. Demography, 38: 147-159. https://doi.org/10.1353/dem.2001.0011

Kligman, G. (2001): On the social construction of „otherness” identifying” the Roma" in post-socialist communities. Review of Sociology, 7(2):61-78. http://dx.doi.org/10.1556/RevSoc.7.2001.2.4

Ladány J. (1996): Romák Közép-Kelet-Európában. Társadalmi Szemle, 51(4): 27-41.

Ladányi J. - Szelényi I. (2002): Cigányok és szegények Magyarországon, Romániában és Bulgáriában. Szociológiai Szemle, 4: 72-94.

Lőrincz L. (2006): A vonzás szabályai - Hogyan választanak társat az emberek? Szociológiai Szemle, 2: 96-110.

Lőrincz L. (2013): A magyar középiskolások párválasztási preferenciái: a roma-nem roma heterogenitás hatása. Szociológiai Szemle 24(2): 47-64.

Mallman,M.(2017):NotEntirelyatHome:UpwardSocialMobilityandEarlyFamilyLife. Journal of Sociology, 53(1): 18-31. https://doi.org/10.1177/1440783315601294

Marion Young I: (1990): Justice and the Politics of Difference. New Jersey: Princeton.

Naudet J. (2018): Stepping into the Elite: Trajectories of Social Achievement in India, France, and the United States. India: Oxford University Press.

Nyírő, Zs. - Durst, J. (2021): Racialisation rules: The effect of educational upward mobility on habitus. Szociológiai Szemle, 31(3), 21-50.

https://doi.org/10.51624/SzocSzemle.2021.3.2 
Reay D. (2015): Habitus and the psychosocial: Bourdieu with feelings. Cambridge Journal of Education, 45(1): 9-23. https://doi.org/10.1080/030576 4X.2014.990420

Ridgeway C. L. (2009): Framed before we know it: How gender shapes social relations. Gender \& society, 23(2): 145-160. https://doi.org/10.1177/0891243208330313

Seccombe W. (1974): The Housewife and Her Labour Under Capitalism. New Left Review, 83: 3-24.

Swartz, D. (1997): Culture and Power. The Sociology of Pierre Bourdieau. ChicagoLondon: University of Chicago.

Szalai J. (2002): A társadalmi kirekesztődés egyes kérdései az ezredforduló Magyarországán. Szociológiai Szemle, 4: 34-50.

Szikra D. (2018): Ideológia vagy pragmatizmus? Családpolitika az orbáni illiberális demokráciában. In Bozóki A. - Füzér K. (szerk.) Lépték és irónia. Szociológiai kalandozások. Budapest: L’Harmattan: 219-240.

TóthÁ. - Vékás J. (2008): Család és identitás: A vegyes házasság szerepe a magyarországi kisebbségi közösségek reprodukciójában. Demográfia, 51(4): 329-355.

Yuval-Davis N. (2006): Intersectionality and Feminist Politics. European Journal of Women's Studies, 13(3): 193-209. https://doi.org/10.1177/1350506806065752

Walby, S. (1990): Theorising Patriarchy. Oxford - Cambridge: Basil Blackwell Ltd.

Wright E. O. (2003): Social class. In George R.-Thousand O. (ed.) The Encyclopedia of Social Theory, California: Sage Publications.

Watson, P. (1993): Eastern Europe Silent Revolution: Gender. Sociology 27(3): 471-487.

Zimmermann S. (2010): Gender Regime and Gender Struggle in Hungarian State Socialism. In Aspasia. International Yearbook for Women's and Gender History of Central, Eastern and Southeastern Europe, 4:1-24. 